\title{
Do Pulmonologists Need to Tighten up Their Sphincter Tone? Do Pulmonologists Need More Guts?
}

\author{
Marc Noppen Kayvan Amjadi \\ Interventional Endoscopy Clinic, University Hospital AZ-VUB, Brussels, Belgium, and Division of Respirology \\ and Critical Care Medicine, Queen's University, Kingston, Canada
}

Although reports on transbronchial needle injections (TBNI) were made as early as 1965 , a systematic review of its application has only recently been reported by Seymour et al. [1] in this current issue of Respiration. This paper is an interesting and comprehensive overview of the published literature on the diagnostic and therapeutic capabilities of TBNI, with special emphasis on its role in the management of various pathological conditions using specific injectable agents. Surprisingly, TBNI has not gained much popularity amongst bronchoscopists, resulting in no randomized controlled trials that can effectively demonstrate its potential value as an armament in the pulmonologists' fight against various respiratory diseases.

In contrast, this technique is widely used effectively by our gastroenterology colleagues as a management modality for a variety of digestive tract diseases: ethoxysclerol [2], human thrombin [3], histoacryl [4] or polidocanol [5] for bleeding peptic ulcers, botulinum for achalasia [6], Nbutyl-2-cyanoacrylate for pancreatic fistulas [7], inert implantable materials and non-resorbable copolymers for gastroesophageal reflux disease [8,9], enbucrilate for mycotic aneurysms [10], hydroxypropyl methylcellulose or photocrosslinkable chitosan for cancer or polyp resection $[11,12]$, or alcohol, various anticancer agents and local immunotherapy for digestive tract cancers [13], to mention a few.

The reason for this disparity between gastroenterologists and pulmonologists is unclear. One may postulate that there are more gastroenterologists with expertise in delivering endoscopic therapies due to the higher incidence of gastrointestinal (GI) diseases (such as bleeding peptic ulcer) that are amenable to such therapeutic modalities. The other reason (and a more philosophical one) may have something to do with the basic characteristics of GI or pulmonary physicians. Could it be that the physicians who choose gastroenterology as a profession are more likely to take (calculated) risks than those who choose pulmonary medicine? In other words, are the GI folks 'gutsier' than the pulmonologists when it comes to performing procedures?

This unfortunately seems to be at least in part true. Although pulmonologists do an outstanding job unravelling complex pulmonary cases, and have excellent command over pulmonary physiology and function, they seem to shy away from their bronchoscope, and appear to consider it as an awkward, difficult-to-handle instrument whose sole purpose is to make life more difficult for the patient and the physician. Surveys have shown that the majority of pulmonologists use the bronchoscope mainly for tissue diagnosis of a suspected pulmonary lesion, assessment of hemoptysis, and occasionally for identifying an infectious agent, or determining the cause for a patient's interstitial lung disease. Only a minority uses the instrument for techniques that are unfortunately considered as 'more elaborate'. For instance, only a quarter of pulmonologists ever perform transbronchial needle aspiration, while only $15 \%$ perform interventional techniques such as electrocautery or stenting [14].

\section{KARGER \\ Fax +4161306 1234 E-Mail karger@karger.ch} www.karger.com
(C) 2006 S. Karger AG, Base 0025-7931/06/0731-0018\$23.50/0

Accessible online at: www.karger.com/res
Prof. Marc Noppen

Interventional Endoscopic Clinic

University Hospital AZ-VUB, Laarbeeklaan 101

B-1090 Brussels (Belgium)

Tel. +32 2477 6010, Fax +32 2477 6840, E-Mail marc.noppen@az.vub.ac.be 
The study by Seymour et al. [1] is therefore pivotal: not only does it extensively review the published literature on the potential application of TBNI providing encouragement for future research in this field, but it also makes us realize that the bronchoscope is more than a 'necessary evil'. Flexible bronchoscopy, when performed by well-trained professionals using careful preparation (local anesthesia, judicious use of sedatives), is equally or even better tolerated than gastroscopy [pers. unpubl. data]. Once one has mastered the instrument, expansion of its indications and use will follow automatically. Thus, without using the word 'TBNI', we have used the bronchoscope to inject corticosteroids in the prevention of bronchial stenosis in cases of endobronchial tuberculosis [15], injected adenovirus-mediated wild-type p53 for treatment of lung cancer [16], and have inserted gelfoam in the treatment of bronchopleural fistulas [17]. It is probable that there are several other interesting unreported cases by other pulmonologists who require encouragement and opportunity to publish and share their experience. We are convinced that in the future many pulmonologists will expand the use of the bronchoscope beyond the simple tumor biopsy or bronchial aspirate, once they have learned to master and appreciate this tool.

Therefore, the lessons to be learned from this paper, are:

1 Learn to appreciate the bronchoscope: review your technique, correct it when necessary, and expand its use.

2 Do not shy away from using your bronchoscope when indicated: your patients may not love it, but they do prefer it over other endoscopic modalities.

3 Browse through the GI literature from time to time: it may provide you with some novel ideas that may apply to bronchoscopic procedures.

4 Report your TBNI experiences and ideas; collaborate with others, and design and perform randomized, controlled trials.

In order to achieve these goals it may be that pulmonologists need to become more 'gutsy' and accept taking calculated risks with the bronchoscope in order to expand the therapeutic modalities that could be provided to our pulmonary patients.

\section{References}

1 Seymour CW, Krimsky WS, Sager J, Kruklitis RJ, Lund ME, Musani AI, Sterman DH: Transbronchial needle injection: a systematic review of a new diagnostic and therapeutic paradigm. Respiration 2006;73:78-89.

2 Dhiman RK, Chawla YK: A new technique of combined endoscopic sclerotherapy and ligation for variceal bleeding. World J Gastroenterol 2003;9:1090-1093.

3 Norton ID, Wang L, Levine SA, Burgartt LJ, Hofmeister EK, Rumalla A, Gostout CJ, Petersen BT: Efficacy of colonic submucosal saline solution injection for the reduction of iatrogenic thermal injury. Gastrointest Endosc 2002;56:95-99.

4 Binmoeller KF, Soehendra N: New haemostatic techniques: histoacryl injection, banding/endoloop ligation and haemoclipping. Baillières Best Pract Res Clin Gastroenterol 1999;13: 85-96.

5 Ljubicic N, Supanc V, Vrsalovic M: Efficacy of endoscopic clipping for actively bleeding peptic ulcer: comparison with polidocanol injection therapy. Hepatogastroenterology 2004;51: 408-412.

6 Zaninotto G, Annese V, Del Genio A, Constantino M, Epifani M, Gatto G, D'onofrio V, Benini L, Contini S, Molena D, Tardio B, Andriulli A, Ancona E: Randomized controlled trial of botulinum toxin versus laparoscopic heller myotomy for esophageal achalasia. Ann Surg 2004;239:364-370.
7 Seewald S, Brand B, Groth S, Omar S, Mendoza G, Seitz U, Yasuda I, Xikun H, Nam VC, $\mathrm{Xu} \mathrm{H}$, Thonke F, Soehendra N: Endoscopic sealing of pancreatic fistula by using N-butyl2-cyanoacrylate. Gastrointest Endosc 2004; 59 : 463-470.

8 Lehman GA: Injectable and bulk-forming agents for enhancing the lower esophageal sphincter. Am J Med 2003;115(suppl 3A): 188S-191S.

9 Deviere J, Costamagna G, Neuheus H, Voderholzer W, Louis H, Tringali A, Marchese M, Fiedler T, Darb-Esfahani P, Schumacher B: Nonresorbable copolymer implantation for gastroesophageal reflux disease: a randomized sham-controlled multicenter trial. Gastroenterology 2005;128:532-540.

10 Ferrari AP, Ferreira JP, de Paulo GA, Libera ED Jr: Hemobilia caused by a mycotic aneurysm of the hepatic artery treated by enbucrilate injection during ERCP. Gastrointest Endosc 2003;57:260-263.

11 Feitoza AB, Gostout CJ, Burgart LJ, Burkert A, Herman LJ, Rajan E: Hydroxypropyl methylcellulose: a better submucosal fluid cushion for endoscopic mucosal resection. Gastrointest Endosc 2003;57:41-47.
12 Hayashi T, Matsuyama T, Hanada K, Nakanishi $\mathrm{K}$, Uenoyama M, Fuyita M, Isihara M, Kikuchi M, Ikeda T, Tajairi H: Usefulness of photocrosslinkable chitosan for endoscopic cancer treatment in alimentary tract. J Biomed Mater Res B Appl Biomater 2004;71:367372.

13 Bhutani MS: Endoscopic ultrasound guided antitumor therapy. Endoscopy 2003;35:S54S56.

14 Smyth CM, Stead RJ: Survey of flexible fibreoptic bronchoscopy in the United Kingdom. Eur Respir J 2002;19:458-463.

15 Verhaeghe W, Noppen M, Meysman M, Vincken W: Rapid healing of endobronchial tuberculosis by local endoscopic injection of corticosteroids. Monaldi Arch Chest Dis 1996; 51:391-393.

16 Schuler M, Hermann R, De Greve JL, Stewart AK, Gatzemeier U, Stewart DJ, Laufman L, Gralla R, Kuball J, Heussel CP, Kommoss F, Perruchoud AP, Shepherd FA, Fritz MA, Horowitz JA, Huber C, Rochlitz C: Adenovirus-mediated wild-type p53 gene transfer in patients receiving chemotherapy for advanced non-small-cell lung cancer: results of a multicenter phase II study. J Clin Oncol 2001;19: 1750-1758.

17 Lois M, Noppen M: Bronchopleural fistulas: an overview of the problem with special focus on endoscopic management. Chest 2005;128: 3955-3965. 